\title{
Sustainability in Soybean Production from the Perspective of the Producers
}

\author{
Bianca Bigolin Liszbinski ${ }^{1}$, Eliane Spacil de Mello ${ }^{2}$, Maria Margarete Baccin Brizolla ${ }^{2}$, Argemiro Luís Brum², \\ Tiago Zardin Patias ${ }^{1} \&$ Daniel Knebel Baggio ${ }^{2}$ \\ ${ }^{1}$ Departament of Administration, Federal University of Santa Maria, Palmeira das Missões, Brazil \\ ${ }^{2}$ Post Graduate Program in Regional Development, Northwest Regional University of the State of Rio Grande do \\ Sul, Ijuí, Brazil \\ Correspondence: Bianca Bigolin Liszbinski, Departament of Administration, Federal University of Santa Maria, \\ Palmeira das Missões, Brazil. E-mail: biancabigolin@gmail.com
}

Received: February 23, $2020 \quad$ Accepted: April 3, 2020 Online Published: April 8, 2020

doi:10.5539/jms.v10n1p138 URL: https://doi.org/10.5539/jms.v10n1p138

\begin{abstract}
This study aims to analyze the sustainability in the context of soybean cultivation by the cultivators' perspective. The research is descriptive, with quantitative evidences operationalized through the application of questionnaires to a sample of soybean producers in the state of Rio Grande do Sul/Brazil. It was executed descriptive analysis of the profiles of the soybean farmers and the properties and technical-agronomic aspects profiles, then subsequently, a correlation analysis between variables from the producers and properties profiles with the environmental, social and economic of sustainability dimension. By the result of the research, it was observed that the majority of soybean producers have been doing this work for 30 years, with low schooling. In addition, regarding the structure of the properties, the area intended for soybeans varies in the sample from 5 to 2,300 hectares, with $25.1 \%$ of producers allocating more than 296 hectares for this cultivation. In the production process, it was noticed that most producers use different inputs, such as herbicides, insecticides, fungicides and fertilizers, besides the care with the soil through the use of no-tillage system and search from crop diversification. In producers' perspective of the sustainability, it is identified some significant associations between certain producers' profiles and property variables with environmental, economic and social topics. However, the evidences, it is suggested a wariness from these analyses, since there is a disagreement in the literature on sustainability in agricultural activities, such as soybeans, because of the complexity of assessing the performance of farmer perception and sustainability indicators.
\end{abstract}

Keywords: sustainability, soybean, soybean cultivation

\section{Introduction}

The estimated of grains production in Brazil for the 2018/2019 crop reaches 236.7 million tons, which represents an increase of $9 \%$ from the previous crop, in a planted area of approximately 63 million hectares. Of this total amount, soybean production contributes 114.3 million tons, and in this last season there was a $1.9 \%$ increase in the area of planting of this grain compared to 2017/2018 (Conab, 2019).

These initial data represent the relevance of soybean production in the context of Brazilian agribusiness and its influence on several other economic sectors. According to Hirakuri et al. (2014) besides soy being the most produced grain in Brazil, widely sold internally and externally, this grain is related with one of the largest industrial complexes in the country, involving numerous companies from small to transnational, besides being the production with higher consumption. As observation, it is worth noting that there are several agents involved in the soy production chain, such as the input industry, the machinery and implement industry, the originators, the exporters, as well as the producers (Santana, 2005).

One of these factors is sustainability in soybean production, specifically, not only the economic prominence, but the social environmental emphasis of this productive activity must be concerned. In the social sphere, for example, the soy production chain generates a significant amount of direct and indirect jobs. Regarding environmental objective, it is detected an antagonism in soy production (Hirakuri et al., 2014), providing on one hand the requirement for efficient food production and on the other, strong pressure to combat deforestation and 
environmental degradation arising from the adopted productions system through the implementation of public and private environmental conservation policies (Lima et al., 2019).

As discussed by Tilman et al. (2002), increasing global food demand, including soybeans, pose enormous challenges to the sustainability of both food production and terrestrial and aquatic ecosystems. Consequently, farmers are considered key players in caring for the areas of land used for agricultural production in a global context and may perhaps irreversibly shape this land in the near future. Incentives and policies to ensure sustainability in agriculture are considered crucial to meeting demands for productivity improvement without compromising environmental integrity or population health.

Considering this statement, it is analyzed that soy production is seen within a complex system which seeks to improve its sustainable characterics, providing several factors of influence, whether economic, social or environmental (Hirakuri et al., 2014; Lima et al., 2019). On one hand there are the demands of the consumer market and society in general, on the other hand, there are the needs of the soy producer, who pursue to remain in an increasingly challening context (Lima et al., 2019). In view of these factors, the objective of this study is to analyze sustainability in soy production, based on the perception of producers. This research bias seeks evidence of the economic, social and environmental parameters in the context of property, aiming to characterize soybean production in Rio Grande do Sul/Brazil, the brazilian state with the second largest producer of the grain in Brazil and the one with the highest number of establishments related to this type of cultivation (Ibge, 2017).

It is noticed that studies supporting this proposal for the relationship between soy production and sustainability shared to explain this situation in different aspects. Zortea et al. (2018), for example, developed a study that sought to assess the sustainability of soy production in the state of Rio Grande do Sul, adopting a life cycle approach for nine impact categories and/or stakeholders. Using primary and secondary data, this study was based on a sustainability indicator and a production life cycle approach.

The study by Kamali et al. (2017), presents another approach, seeking to evaluate the environmental, economic and social performance of soybean cultivation in southern Brazil, based on information from plantation farms, Embrapa (Brazilian Agricutural Research Corporation) and specialists in the area. This research was focused on five sustainability issues: global warming, area of occupation, use of primary energy, profitability and employment.

Therfore, this study proposal differs due to the methodological and practical factors being directed exclusively to soybean producers. Methodologically, a research instrument that seeks evidence of sustainability was used, based on the theory available on this topic in different fields of knowledge, in addition to that related to the technical production of soy. In practical terms, the research was applied to a sample of soybean producers in one of the Brazilian states that has one of the highest productivity rates, seeking to identify, in addition to their profile, their actions that reflect in sustainable terms.

\section{Sustainable Agriculture}

The construction of the concept about sustainability terminology is a task that is in continuous improvement due to the fact that there are several research fronts that approach this theme from different conceptions (Marconatto et al., 2013; Froehlich, 2014). It can be considered that the discussions were strengthened from the Brundtland Report (1987), which was prepared by the World Commission for Environmental Development and brings the most widespread definition on the theme: sustainable development is the one that suppresses the needs of the present without compromising the ability of future generations to meet their needs.

In a context of sustainable development, the issue of economic development is observed in addition to social equity and environmental balance, factors that must acquire harmonious meanings (Donaire, 1999). In other words, Prates et al. (2015, p. 5) affirm that "sustainability has been assuming a central role in reflections on the dimensions of development", allowing it to be measured and analyzed from different perspectives in a given activity or context.

Among the possibilities of sustainability analysis, the dimensions most frequently used are those related to economic, social and environmental issues, as a result of the methodology known as the Triple Bottom Line (Elkington, 1997, 2004). This form of measurement comes from the field of organizations, however, these three dimensions are considered consensus among a large part of the authors because it is possible to analyze them in different contexts:

a) economic dimension of sustainability: defends that the profits from activities come from the responsible management of resources from public or private investments, always respecting the other dimensions of sustainability; 
b) environmental dimension of sustainability: refers to the available and exploited resources of nature, that is, this dimension addresses the care that must be taken in productive activities so that ecosystems maintain their capacity for recomposition, even with the interference of man;

c) social dimension of sustainability: deals with the possibility for the individual and the community to have their basic needs met, such as health, education and citizenship, including the equal distribution of income, the valuing of the cultural identity of individuals and the elimination of any discriminatory practice (Dias, 2006; Werbach, 2010; Nascimento, 2012; Hirakuri et al., 2014).

Even though, providing the breadth of the themes involved in each of these three dimensions, it is reported, however, that they are not unanimous in the theoretical field on the different fronts of the study of sustainability. Studies by Spangerber and Bonniot (1998), Pawlowski (2008), Werbach (2010) and the considerations of the Marco Universal (2013), for example, present additional dimensions to those previously mentioned, namely: ecological, demographic, institutional, cultural, spatial, moral, political and technical.

When it comes to the field of agricultural systems, in addition to the dimensions mentioned for mapping sustainability, there are still the inclusion of two basic characteristics: resilience and persistence. Resilience refers to the ability of these systems to minimize possible shocks and stresses, and persistence is related to the fact that these systems continue over time (Petry, 2008).

In agriculture, as well as in other research areas, sustainability is a complex concept and there is no common point of view among scholars on the full measurement of its dimensions. Various parameters to measure agricultural sustainability have been proposed and the evaluation of production chains based on these indicators could support the direction of public policies, the advancement in research, the transfer of technology, technical assistance, among other factors that could assist in reducing of sustainability bottlenecks in this sector (Hirakuri et al., 2014).

Even if there is no unanimity in terms of the concept of agricultural sustainability, what stands out in terms of dimensions to be used for analysis in this area is that sustainable agriculture has become synonymous with environmentally friendly, economically viable and socially agricultural production desirable (Schaller, 1993). In this sense, Sydorovych and Wossink (2008) corroborate the idea that an integrated measure of global agricultural sustainability could be assessed through a joint analysis of economic, social and ecological attributes. These authors also emphasize that the adoption of numerous indicators to analyze agricultural sustainability can trigger difficulties when putting this proposal into practice, especially in the case of possible comparisons in the study and between different production systems, in addition to the problem of estimates of minimum and maximum scales for each attribute.

In practical terms, agriculture is considered an essential partner in sustainable development. This statement comes from its importance in providing essential goods for human health, survival and well-being. In this sense, most concerns about sustainability in agriculture focus on the need to develop technologies and practices that have no adverse effects on environmental goods and services, that are accessible and effective for farmers, reflecting improvements in food productivity (Xavier et al., 2018).

In this context, it is worth noting the progress in agricultural productivity in recent years, due to factors such as increased use of fertilizers, irrigation systems, sophisticated agricultural machinery, pesticides and the growing number of productive land areas. However, it is necessary to be aware that these results may not remain linear in the future, and new technologies and forms of production may be necessary to meet the food needs of society, in addition to seeking to minimize the use of non-renewable inputs, which would cause damage the environment and even the health of farmers and consumers (Petry, 2008).

There are significant possibilities for analysis with regard to agricultural sustainability, whether due to the different productive activities developed, the extent and forms of coordination of rural properties, the behavior of final consumers, production regions, the production chain involved, among others. factors (Lynch et al., 2019). Considering these factors and the delimitation of the object of this study, specific aspects of soy production are addressed in the following section.

\section{Sustainability in Soy Production}

The soybean culture started in Brazil from the State of Rio Grande do Sul/Brazil during the 1970s, without much expression. Over time this cultivation migrated, respectively, to the states of Paraná, Mato Grosso do Sul and later to the other regions of the country. This advance was accompanied by technological evolution linked to culture, increased productivity, resistance to diseases of this cultivar, adequate plant nutrition, improvement in soil management and mechanization of culture (Gazzoni, 2013).

For the 2018/2019 harvest, it is estimated that the area destined for soybean planting at the national level is 35,802 
million hectares, which represents an increase of 1.9\% in relation to the 2017/2018 harvest, being that the Midwest and South regions assume more than $78 \%$ of this production. In this last harvest $2018 / 2019$, soybean productivity reached 3,193 kg/ha, different from the 2,823 kg/ha presented in the 2016/2017 period, which may be providing a significant increase in terms of profitability for the producer, very especially due to the investments made in the use of technologies applied in production (Conab, 2019).

The impulse observed in soybean production over time is related to several factors. Among the factors that influenced the increase in the relevance of soy in the world context, the high protein content present in the grain stands out, serving for human and animal feed; the considerable presence of oil in the grain that can be used for different purposes, for example, in biofuels and in food; because it is a commodity and has a certain degree of uniformity and standardization; for its ease of use in production technologies (Hirakuri \& Lazzarotto, 2014).

The relevance of this grain and the growing demand shown in this cultivation, there was a need for this production to accompany the contemporary scenario with regard to sustainability issues, especially arising from the consumer market and public policies (Kertész et al., 2014; Oviedo, 2015). Thus, it is not enough just to worry about the amount of soy that is being produced and the profitability that is being generated, but also to dedicate attention to the environmental and social issues linked to this production process.

Overall, the soy production chain has endeavored to present, mainly to the foreign market, that Brazilian soy is produced in a sustainable way, for example, without degrading the environment by removing forests due to deforestation (Lima et al., 2019) to expand the area produced. Nonetheless, in addition to this factor, other issues influence sustainability in the scope of soy.

In this context, reflections were triggered about parameters that would assist in the analysis of the sustainability of the soy production chain, and more specifically, in the production of that grain. In the Brazilian context, the methodology developed by Hirakuri et al. (2014) covers three main axes - environmental-agronomic, social and environmental - in line with what was stressed in the previous section when addressing the possibilities of evidencing sustainability in agricultural activities from the economic, environmental and social standpoint.

Among the several possible parameters to analyze sustainability in soy production, we mention:

a) in the environmental-agronomic dimension: use of pesticides, use of fertilizers and correctives, seed inoculation, soil management, number of crops per year, pest and weed management;

b) in the economic dimension: soybean productivity, remuneration to the producer, storage capacity, possession of the planted area, flow of the harvest and return on investment;

c) in the social dimension: use of pesticides, employment and income for workers and human development (Hirakuri et al., 2014).

It is good to point out the different methods of analyzing sustainability in the context of soybeans can be used. However, most of the models developed and applied refer to agricultural activities in general. The proposal presented by Sydorovych and Wossink (2008), for example, brings social, ecological and economic attributes that would form a global measure of sustainability, from the perception of different stakeholders linked to agricultural activity.

The study by Limón and Fernandez (2010) aimed to measure sustainability in two different agricultural systems based on the concept of economic, social and environmental components. These authors highlight in their discussions the heterogeneity in the context of the farms analyzed, within the same agricultural system, in relation to the understanding of sustainability, making it clear, the complexity of this theme in the agricultural sector.

Xavier et al. (2018) sought to study sustainable agriculture from a regional context. In general, they state that sustainability can be analyzed using different types of indicators - economic, social and environmental — however, they understand that quantification and aggregation in a single index is difficult considering the heterogeneous characteristics of each region or cultivation developed.

Lynch et al. (2019) analyzed the sustainable agricultural potential in a group of Irish farms. They observed that the trend is to expand the range of sustainability indicators adopted, whether in the environmental, economic or social spheres, even if at first this fact seems to be onerous, especially for those producers focused on only one aspect of sustainability.

In previous studies, it is adressed the sustainable context of soy, Ferreira et al. (2017). These authors applied the methodology proposed by Hirakuri et al. (2014), in a microregion of the state of Paraná, using secondary data. From the metrics used, for the environmental-agronomic dimension most of the indicators were classified as good sustainability, while in the social and economic ones they were mostly classified as low sustainability. 
By this context, there is a possibility to explore with greater emphasis on sustainability specifically in soy production. Thus, the following section presents the methodological outline that supports the proposal of this search.

\section{Method}

This study has the general aspiration of analyzing the sustainability of soy production from the perception of the producers of this crop. Accordingly, the research is characterized as being descriptive and quantitative. The classification according to these precepts takes into account the fact that observations and analyzes will be carried out in order to register and correlate phenomena without manipulating them (Rampazzo, 2002).

The target population of the study comprises soy producers in the state of Rio Grande do Sul/Brazil, which according to data from the Agricultural Census (Ibge, 2017), form a total of 95,394 producing establishments. The final sample of the study is composed of 179 participants, this quantitative, obtained through the accessibility criterion, being a non-probabilistic sample, as specified by Cooper and Schindler (2016). As a form of data collection, the strategy of direct questionnaire application and online platform was adopted. According to Malhotra (2012), this second option has been adopted more frequently in research due to easy access to the target population, agility and lower cost.

As a research instrument it was used the questionnaire, structured on models already used in previous studies and according to what the literature recommends on the themes of sustainability and soy production, being subdivided into four question blocks, according to data of Table 1. It should be noted that this instrument was initially validated by an agronomist, due to the fact that it contains technical-agronomic specifications for soybean production. Subsequently, and before the final collection, the pre-test procedure was carried out with five producers in order to ensure the clarity and understanding of the adopted terminology.

Table 1. Parameters of the research instrument

\begin{tabular}{lll}
\hline Section I & Respondent Profile & Self elaboration \\
Section II & Respondent Profile & Self elaboration \\
Section III & Characteristics of Soy Production & Adapted from Hirakuri et al. (2014) \\
Section IV & Perception of Sustainability in the Economic, Social and & Adapted from Hirakuri et al. (2014); Ross et al. (2015); \\
& Environmental Dimensions & Patias (2017); Ethos (2018) \\
\hline
\end{tabular}

Throughout the data collection, these were tabulated and later analyzed using the Statistical Package for the Social Sciences-SPSS software. As a way of evaluating the results, descriptive statistics were used to analyze the profile questions of the respondents and the property, in addition to the characteristics of soybean production. In addition, we sought to correlate certain profile variables with the perception of sustainability according to the environmental, economic and social dimensions.

The correlation analysis follows the criteria established by Pestana and Gageiro (2003). In consequence of that, the normality of the distribution was initially analyzed using the non-parametric test of adherence to normality Kolmogorov-Smirnov (KS) with the correction of Lilliefors, and the level of significance of the test was less than 0.05 , thus rejecting the hypothesis that the distribution is normal. Thus, Spearman's coefficient was used to verify the association between variables, which is explained in the following section.

\section{Results and Discussions}

\subsection{Data Description}

In relation of the investigated sample, 179 responses were obtained from soybean producers from different municipalities in the State of Rio Grande do Sul/Brazil. Table 2 shows the characterization of the profile of these producers, according to the variables of age, soybean production time and schooling. 
Table 2. Respondent profile

\begin{tabular}{llll}
\hline VARIABLES & CLASSIFICATION & FREQUENCY & \% \\
\hline AGE & Up to 32 years old & 51 & 28.5 \\
& From 33 to 43 years old & 45 & 25.1 \\
& De 44 a 52 years old & 39 & 21.8 \\
\multirow{2}{*}{ TIME IN SOY PRODUCTION } & More than 53 years old & 44 & 24.6 \\
& Less than 10 years & 36 & 20.1 \\
& From 10 to 20 years & 52 & 29.1 \\
& From 20 to 30 years & 35 & 19.6 \\
SCHOOLARITY & More than 30 years & 56 & 31.3 \\
& Elementary school incomplete & 32 & 17.9 \\
& Elementary school complete & 23 & 12.8 \\
& High school incomplete & 20 & 11.2 \\
& High school complete & 44 & 24.6 \\
& Graduation incomplete & 19 & 10.6 \\
& Graduation complete & 29 & 16.2 \\
\hline
\end{tabular}

As result of the age of soybean producers, most respondents are up to 32 years old (28.5\%), followed by a group between 33 and 43 years old (25.1\%); very close are those surveyed over 53 years old (24.6\%) and the minority of producers is in the group aged 44 to 52 years $(21.8 \%)$.

As for the time of soy production, the survey revealed that the majority of producers have been in the activity for more than 30 years $(31.3 \%$ ), which may demonstrate a follow-up of the family in production. Then there are those who are 10 to 20 years old producing soybeans $(29.1 \%$ ), after the producers who have been in the activity for less than 10 years (20.1\%) and finally the producers who are 20 to 30 years in this sector (19.6\%).

In terms of schooling, the survey showed that $24.6 \%$ of soy producers attended high school, while $17.9 \%$ had only incomplete elementary school. Already $16.2 \%$ demonstrated having completed higher education, followed by $12.8 \%$ with complete elementary education, while $11.2 \%$ said they had incomplete high school, $10.6 \%$ of respondents said they had incomplete graduation and only $6.7 \%$ had complete postgraduate training.

To characterize the sample, an analysis of the profile of the soy producing properties was made, according to data presented in Table 3. Regarding the size of the properties, the research revealed that most (26.3\%) have up to 50 hectares, the same percentage of properties that have between 51 and 120 hectares. Next are properties with more than 341 hectares (25.2\%) and, finally, properties with 121 to 340 hectares (22.3\%).

Table 3. Property profile

\begin{tabular}{|c|c|c|c|}
\hline VARIABLES & CLASSIFICATION & FREQUENCY & $\%$ \\
\hline \multirow[t]{4}{*}{ TOTAL PROPERTY SIZE } & Up to 50 acre & 47 & 26.3 \\
\hline & From 51 to 120 acre & 47 & 26.3 \\
\hline & From 121 to 340 acre & 40 & 22.3 \\
\hline & More than 341 acre & 45 & 25.2 \\
\hline \multirow[t]{4}{*}{ SOY PRODUCTION AREA } & Up to 40 acre & 48 & 26.8 \\
\hline & From 41 to 100 acre & 47 & 26.3 \\
\hline & From 101 to 295 acre & 39 & 21.8 \\
\hline & More than 296 hectares & 45 & 25.1 \\
\hline \multirow[t]{3}{*}{ ANNUAL GROSS REVENUE } & Until R $\$ 415.000,00$ & 101 & 56.4 \\
\hline & From $\mathrm{R} \$ 415.001,00$ to $\mathrm{R} \$ 2$ million & 56 & 31.3 \\
\hline & More than $\mathrm{R} \$ 2$ million & 22 & 12.3 \\
\hline \multirow[t]{5}{*}{ HIRING LABOR } & No & 97 & 54.2 \\
\hline & Yes, from 1 to 2 employees & 51 & 28.5 \\
\hline & Yes, from 3 to 5 employees & 18 & 10.1 \\
\hline & Yes, from 6 to 10 employees & 11 & 6.1 \\
\hline & Yes, 11 or more employees & 2 & 1.1 \\
\hline
\end{tabular}

By the total size of the properties, an analysis was made only of the area used for soybean cultivation, where the research showed that $26.8 \%$ allocate up to 40 hectares for soybean cultivation, $26.3 \%$ use 41 to 100 hectare, while $25.1 \%$ allocate more than 296 hectares and only $21.8 \%$ of the properties said they allocate from 101 to 295 hectares for the cultivation of soy. In addition, it was identified that when it comes to the area intended for soybean cultivation, $30.2 \%$ of producers stated that they increased this area by comparing the 2019 harvest with the 
previous one.

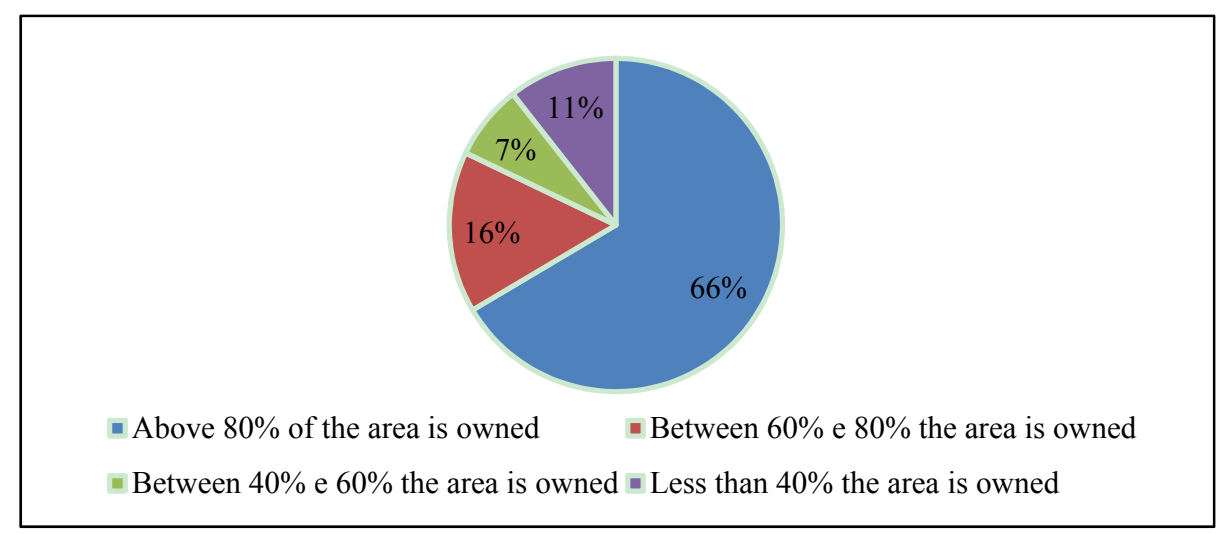

Figure 1. Land area ownership

From the area cultivated with soybeans, the question of ownership of this area was analyzed, which is shown in Figure 1, showing that most producers have their own area above $80 \%$, which indicates excellent sustainability according to Hirakuri et al. (2014). It was identified that $66 \%$ of the production is developed in a predominantly own area.

It was identified, the characterization of the property regarding the cultivation or production and commercialization of other products, besides the soybean. Of the total respondents, $34(19 \%)$ stated that they are dedicated only to the cultivation of soy and $145(81 \%)$ also indicate the cultivation or production and sale of other products. Among these products other than soy, we can mention: wheat, oats, flaxseed, corn, barley, canola, rye, ryegrass, sorghum, beans, tobacco, cassava, potatoes, beef cattle, milk, peaches and grapes.

From the investigated sample, it was sought to classify according to its gross annual revenue, and this framework is used by the national financial system in order to grant rural credit. Thus, most producers $(56.4 \%)$ claim to earn revenue of up to $\mathrm{R} \$ 415,000.00$, while $31.3 \%$ of $\mathrm{R} \$ 415,001.00$ up to $\mathrm{R} \$ 2$ million and $12.3 \%$ said they have higher gross annual revenue to $\mathrm{R} \$ 2$ million reais per year.

Regarding the profile of the properties, there was an incidence of hiring labor, in addition to family members for the activity of soy production. It was found that the majority (54.2\%) do not hire employees, $28.5 \%$ already hire 1 to 2 employees, followed by $10.1 \%$ who hire 3 to 5 employees and $6.1 \%$ who hire between 6 to 10 employees. The minority of the sample (1.1\%) says they hire 11 or more employees.

From the investigated sample, it is necessary to enhance the issue of the relationship between producers and some entity or association, such as unions and cooperatives, which in various situations are the means used to carry out the production business. In this sense, $31.8 \%$ of the respondents affirm that they are not linked to any entity and $68.2 \%$ (122 producers) are associates or partners of some entity related to their productive activity. Among the aforementioned entities are credit unions, agricultural cooperatives, rural employers 'union, rural workers' union and earth-friendly clubs.

In technical terms, the cultivation of soybeans requires several precautions, such as attention to the soil, seed treatment and application of inputs. The care presented in Table 4 are some of the indicators created by Hirakuri et al. (2014) that make this production more or less sustainable. According to these authors, the indicated doses of a pesticide vary significantly according to the target to be controlled, so that the organisms that require higher doses to be controlled increase the vulnerability of the system. For that, an average is made between the lowest and the highest dose or number of applications indicated for a given pesticide.

In general terms, starting from a generic analysis of the results revealed by the research and presented in Table 5, it can be considered that as for the use of herbicides the normal would be 03 applications, the first being Glyphosate + 2.4 D (both in the pre-planting) and a third application in the post-planting of Glyphosate, and as the research showed, most producers (68.7\%) make only 02 applications, which means that there would still be room for more applications.

As for the use of insecticides, it is normal for 03 applications to be made, 02 for caterpillars and 01 for bedbugs. According to the survey, most producers are making only 02 applications in total, also meaning that there is still 
scope for more applications.

For the use of fungicides, the normal agronomic technical recommendation is that an average of 04 applications be made with at least 02 types of fungicides. From what the research has shown, not all producers apply fungicide to soybeans, resulting in $97.8 \%$ making use and, of these, the majority (64.2\%) perform only 03 applications, also leaving room for more applications, therefore, being below the recommended average. Regarding the treatment of seeds, the technical guidance is that this management is indispensable to the production of soy, however, the research revealed that not all producers do it, having shown that $90.5 \%$ do the procedure.

To the use of chemical nitrogen fertilizer, it should be noted that soybeans, as a legume, require less nitrogen fertilization. Thus, the result of the research is as expected, in the sense that not all producers make use of it, therefore, it can be considered normal.

While in the use of phosphate fertilizer, an average considered technically recommended, would be exactly what the survey revealed, that is, of the $82.7 \%$ of producers that use it, the majority $(33.5 \%)$ apply it effectively, also within the average expected. As for foliar fertilization, the agronomic technical recommendation suggests that at least 01 application be made, and the research showed that only $54.2 \%$ of soy producers perform, being technically below expectations.

For the perspective of the seed inoculation, the ideal, according to technical recommendations, would be that all producers use this procedure. The research revealed that only $62 \%$ do this method, and the result obtained is considered proportional to the amount of doses used.

Table 4. Agronomic aspects of soy production

\begin{tabular}{|c|c|}
\hline \multicolumn{2}{|l|}{ HERBICIDE } \\
\hline \multirow[t]{4}{*}{$100 \%$ use it } & Frequency of use \\
\hline & 01 application: $12(6.7 \%)$ \\
\hline & 02 applications: $123(68.7 \%)$ \\
\hline & 03 application: $44(24.6 \%)$ \\
\hline \multicolumn{2}{|l|}{ INSECTICIDE } \\
\hline \multirow[t]{4}{*}{$100 \%$ use it } & Frequency of utilization \\
\hline & 01 application: $14(7.8 \%)$ \\
\hline & 02 applications: $85(47.5 \%)$ \\
\hline & 03 applications: $80(44.7 \%)$ \\
\hline \multicolumn{2}{|l|}{ FUNGICIDE } \\
\hline $2.2 \%$ do not use it & Frequency of utilization \\
\hline \multirow[t]{3}{*}{$97.8 \%$ use it } & 01 application: $18(10.1 \%)$ \\
\hline & 02 applications: $42(23.5 \%)$ \\
\hline & 03 application: $115(64.2 \%)$ \\
\hline \multicolumn{2}{|l|}{ SEED TREATMENT } \\
\hline $9.5 \%$ do not use the procedure & Frequency of who produce: 01 application \\
\hline \multicolumn{2}{|l|}{$90.5 \%$ use the procedure } \\
\hline \multicolumn{2}{|c|}{ CHEMICAL NITROGEN FERTILIZER } \\
\hline $33 \%$ do not use it & Utilization frequency \\
\hline \multirow{3}{*}{$67 \%$ use it } & From 1 to $20 \mathrm{~kg} / \mathrm{ha}: 47(26.3 \%)$ \\
\hline & From 21 to $30 \mathrm{~kg} / \mathrm{ha:} 24(13.4 \%)$ \\
\hline & Over to $31 \mathrm{~kg} / \mathrm{ha}: 49(27.3 \%)$ \\
\hline \multicolumn{2}{|l|}{ PHOSPHATE FERTILIZER } \\
\hline $17.3 \%$ do not use it & Utilization frequency \\
\hline \multirow[t]{4}{*}{$82.7 \%$ use it } & From 5 to $9 \mathrm{~kg} / \mathrm{t}$ of grain: $10(5.6 \%)$ \\
\hline & From 10 to $15 \mathrm{~kg} / \mathrm{t}$ of grain: $48(26.8 \%)$ \\
\hline & From 16 to $20 \mathrm{~kg} / \mathrm{t}$ of grain: $60(33.5 \%)$ \\
\hline & Less than $5 \mathrm{~kg}$ or more than $30 \mathrm{~kg} / \mathrm{t}$ of grain: $30(16.8 \%)$ \\
\hline \multicolumn{2}{|l|}{ FOLIAR FERTILIZATION } \\
\hline $45.8 \%$ do not adopt the procedure & Utilization frequency \\
\hline \multirow[t]{4}{*}{$54.2 \%$ adopt the procedure } & 01 fertilizing: $54(30.2 \%)$ \\
\hline & 02 fertilizations: $34(19 \%)$ \\
\hline & 03 or 04 fertilizations: 7 (3.9\%) \\
\hline & Up to 04 fertilizations: $2(1.1 \%)$ \\
\hline \multicolumn{2}{|l|}{ INOCULATION OF SEEDS } \\
\hline $38 \%$ do not adopt the procedure & Utilization frequency \\
\hline \multirow[t]{3}{*}{$62 \%$ do the procedure } & Inoculate in all the harvests: 95 (53.1\%) \\
\hline & Inoculate every two harvests: $15(8.3 \%)$ \\
\hline & Inoculate in a superior level of four harvests: $1(0.6 \%)$ \\
\hline
\end{tabular}


Producers were asked about the predominant application of inputs in soybean cultivation. Of the total respondents, 06 indicated that they use air services to perform this procedure. 173 producers, representing $96.6 \%$ of the sample, apply the products by means of a sprayer. In this aspect, Embrapa considers that aerial application should only be used in specific situations, but that it is not the main method of applying pesticides in soybean crops, due to factors such as greater vulnerability to product dragging by the wind, due to possible evaporation. of the product before reaching the target (drift or volatilization losses), in addition to the considerable accident rate with registered agricultural aircraft.

About the care with the soil, the producers exposed the actions they adopt. Table 5 presents data related to soil analysis and management and crop diversification.

The evidence indicates to a normality in these actions in the studied sample. The survey revealed, for example, that there is a small number of producers who do not carry out the necessary care, such as chemical analysis of the soil, to verify the degree of need for the use of corrective products.

Table 5. Care soil

\begin{tabular}{lll}
\hline CHEMICAL ANALYSIS OF SOIL & Frequency & $\mathbf{\%}$ \\
& 17 & 9.5 \\
Do not execute & 108 & 60.3 \\
Execute at least 2 years & 35 & 19.6 \\
Execute every 3 years & 18 & 10.1 \\
Execute every 3 years & 1 & 0.6 \\
Execute over 4 years & & $\mathbf{\%}$ \\
CROP DIVERSIFICATION & Frequency & 24.0 \\
& 43 & 31.8 \\
Four or more differente crops in the last five years & 57 & 30.2 \\
Three different crops in the last five years & 54 & 14.0 \\
Two different crops in the last five years & 25 & $\mathbf{\%}$ \\
A crop in the last five years & & 88.3 \\
SOIL MANAGEMENT & Frequency & 8.9 \\
Direct no-till system & 158 & 2.2 \\
No-till with chisel at an interval equal to or greater than 3 years & 16 & \\
Minimal preparation with light grid; or scarifier with intervals less than 3 years; & 4 & 0.6 \\
or heavy harrow or disc plow with an interval of 5 years or more & & \\
Soil preparation with heavy harrow or disc plow less than 5 years apart & 1 & \\
\hline
\end{tabular}

The diversification of crops is also within the expected and considered normal, given that there are not many economically viable alternatives for the producer to carry out, so, what he does is more aimed at protecting the soil and improving soybean productivity. As for soil management, the survey revealed that most producers $(88.3 \%)$ use the no-tillage system, which contributes to the sustainability of soy production.

In economic terms, producers point out that the 2019 harvest had an average yield of 64 bags of soybeans per hectare, and in terms of production costs, $61 \%$ of respondents stated that there was a $20 \%$ increase compared to the 2018 harvest. The product is sold mainly through a partner company or an agricultural cooperative, since most producers do not have the capacity to store production on their own property, which does not favor the direct sale of production that would provide better profitability.

\subsection{Correlation Analysis}

The association between the profile of the producers and the property with the dimensions of sustainability was carried out based on the variables of the questionnaires carried out with the 179 soybean producers, and for this association, the average of each of the constructs was considered. Aiming to identify the association between the studied variables, Spearman's correlation coefficient was used, this test, indicated for non-normal distributions (Pestana \& Gageiro, 2003), as is the case of this study. 
Table 6. Association between soybean production profile and sustainability dimensions

\begin{tabular}{lllll}
\hline PROFILE & ASSOCIATION & $\begin{array}{l}\text { AMBIENTAL } \\
\text { DIMMENSION }\end{array}$ & $\begin{array}{l}\text { ECONOMIC } \\
\text { DIMMENSION }\end{array}$ & $\begin{array}{l}\text { SOCIAL } \\
\text { DIMMENSION }\end{array}$ \\
\hline Age & Correlation Coefficient & -.053 & .050 & -.051 \\
& Significance & .478 & .506 & .498 \\
Production time & Correlation Coefficient & -.055 & -.026 & .009 \\
\multirow{3}{*}{ Schooling } & Significance & .466 & .727 & .905 \\
& Correlation Coefficient & $.167^{*}$ & .075 \\
Total property extension & Significance & .026 & .122 & .319 \\
& Correlation Coefficient & -.007 & .105 & .043 \\
Soybean area extension & Significance & .924 & $.188^{*}$ & .568 \\
\multirow{4}{*}{ Revenue } & Correlation Coefficient & -.005 & .012 & .030 \\
& Significance & .948 & $.183^{*}$ & .687 \\
Production of other products & Correlation Coefficient & .055 & .014 & .080 \\
Membership in entities & Significance & .462 & .143 & .289 \\
& Correlation Coefficient & $.172^{*}$ & .057 & .127 \\
Hiring of labor & Significance & .021 & .091 & $.162^{*}$ \\
& Correlation Coefficient & .055 & .223 & .030 \\
\hline & Significance & .468 & .032 & $.195^{* *}$ \\
\hline
\end{tabular}

Table 6 demonstrate the coefficients and levels of significance of the observed bivariate correlation coefficients. In order to analyze the intensity of the correlation, we took into account what Pestana \& Gageiro (2003, p. 189) establish, that is, "less than 0.2 : very low association; 0.2 to 0.39 : low; 0.4 to 0.69 : moderate; 0.7 to 0.89 : high; 0.9 to 1.0: very high". In view of these parameters, there were 06 significant associations (at $0.005^{*}$ and $0.001^{* *}$ ) between the profile of producers and properties with the dimensions of environmental, economic and social sustainability.

Analyzing the Table 6 results, the associations were significant, the education of producers is correlated with the environmental dimension of sustainability. In other words, the greater the formation of soy producers, the greater their concern with environmental factors, such as, for example, control and reuse of water, observation of issues related to environmental infractions, preservation of springs and forests, care for the soil in production and proper disposal of waste and toxic waste generated. Figure 2 shows environmental variables that presented the highest indexes among all analyzed, that is, those that producers most adopt in soy production.

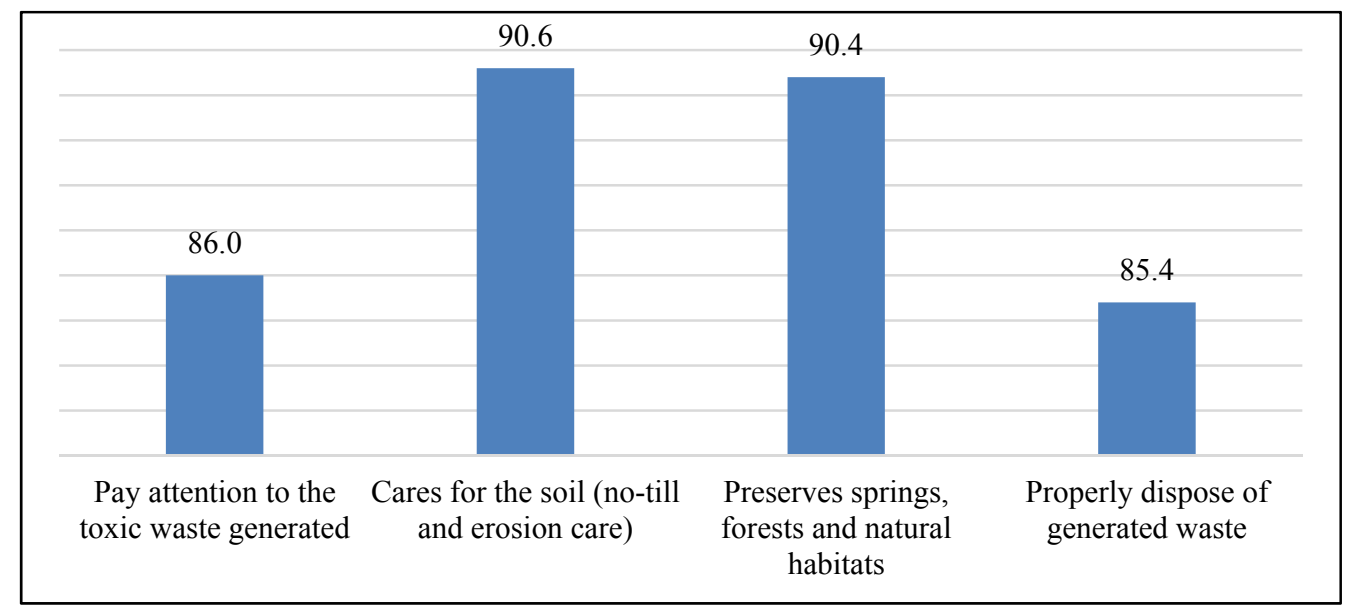

Figure 2. Average percentage of environmental variables

The variables total property size and total extension of the area destined forx soybean cultivation correlated positively with the economic dimension of sustainability. In view of this finding, it is inferred that the greater the extent of the soybean property and area, the greater the perception of producers with indicators such as: increase and satisfaction in the level of sale of the product, increase in the area, productivity and profitability in relation to the previous harvest, greater concern with the level of indebtedness and control of revenues and expenses, in 
addition to an acceptable return on the investment made for soybean production.

Among the economic variables of sustainability analyzed, those that obtained, on average, the highest indexes of agreement by producers are those shown in Figure 3. It is highlighted in this analysis that the concern with the level of indebtedness was the variable with the highest average, with $85.4 \%$.

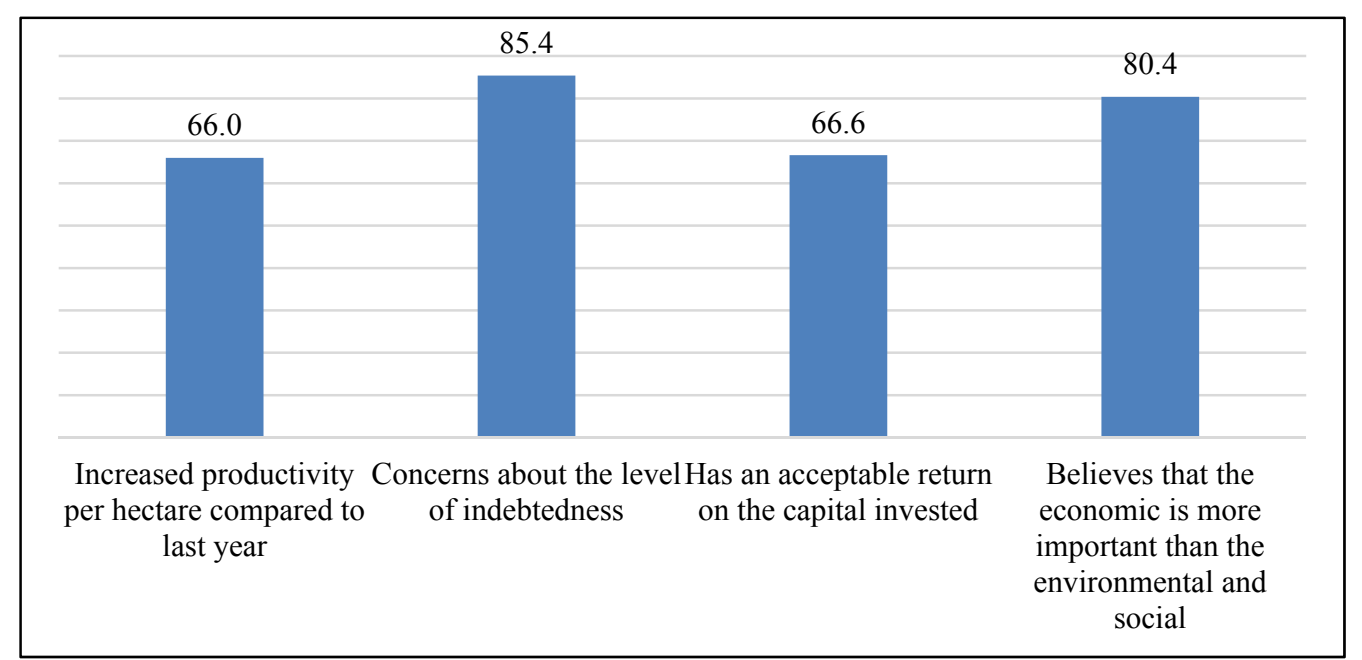

Figure 3. Average of the most significant economic variables

Another association identified was between the environmental dimension of sustainability with the production of other products on the property, in addition to soy. Thus, those producers who cultivate other crops tend to be more concerned with environmental factors. It is worth mentioning that among the other products produced, for example, maize, wheat, oats, sorghum, beef cattle, beans, cassava and barley were identified.

The social dimension of sustainability is positively associated with two profile variables: membership in entities and hiring of labor. Thus, it can be said that those producers who are members of a cooperative, union, club or association and those who hire employees for the activities, in addition to family labor, tend to pay more attention to social indicators sustainability. Among these indicators, we can mention participation and organization of events in the local community, participation and incentive in courses and training related to productive activities, awareness of health and safety at work, concern with the quality of family and family life of workers, attention issues of labor and social security legislation and concern with issues of family succession in productive activities.

As for the social pillar of sustainability, the variables that were most significant are those shown in Figure 4. It is noteworthy that, on average, the concern with accidents at work $(85.8 \%)$ and attention to issues of quality of personal life, the family and its workers $(82.4 \%)$ are the most significant variables.

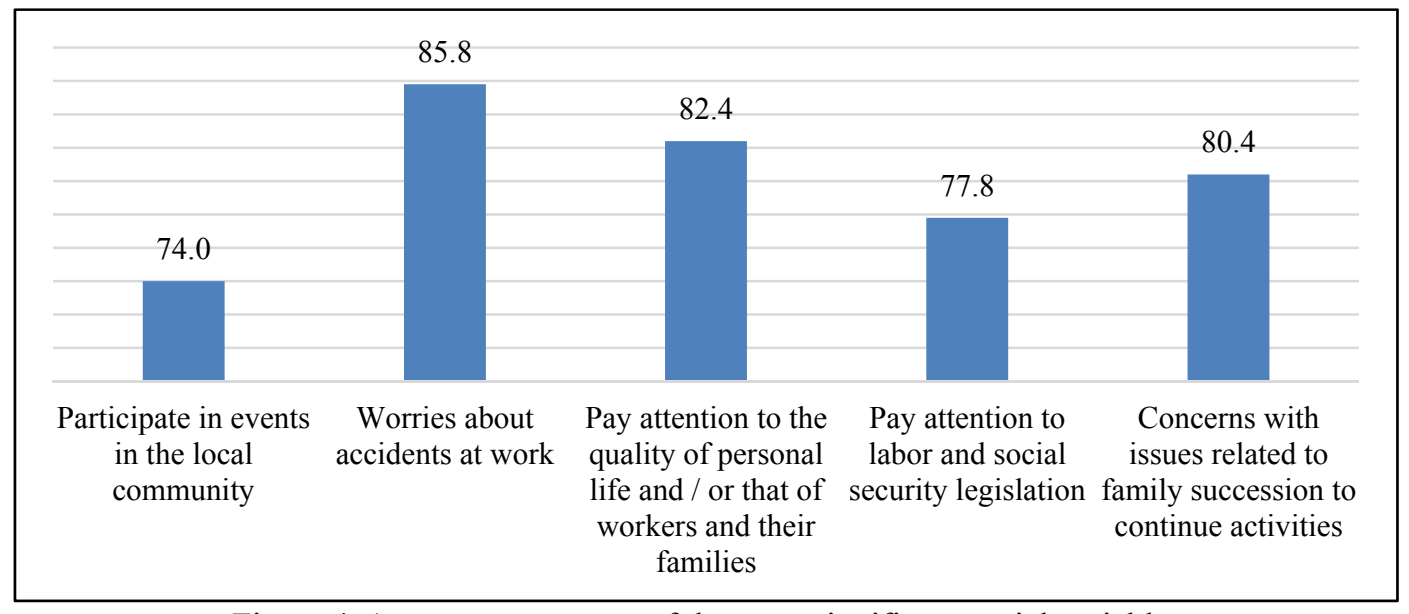

Figure 4. Average percentage of the most significant social variables 
Some of the evidence on the perception of sustainability by soy producers is in line with what exposed Sydorovych and Wossink (2008), who stated that profitability is an important issue for economic sustainability, as well as issues related to worker safety are for social sustainability and attention to water is for environmental sustainability. Even with these data, caution is suggested in the analysis of sustainability indicators for agricultural activities, such as soybeans, since one cannot forget the complexity of finding a single measure to accurately assess the complete well-being of producers with relationship the association between production performance and sustainability issues (Limón \& Fernandez, 2010; Xavier et al., 2018).

\section{Conclusion}

This study intended to analyze aspects related to sustainability in soy production, based on the producers' perception. The research sought evidence of the different sustainable dimensions in the context of the property, aiming to characterize the production of soy in Rio Grande do Sul/Brazil. The choice for the study in this state is related to the fact that it is the second largest producer of this grain in the country, reflecting the relevance of this productive activity both locally, regionally or nationally.

Observing the analysis of the profile of the producers, variations in the sample were identified, for example, that most producers have been producing soybeans for more than 30 years and have only incomplete elementary education. Regarding the structure of the properties, most of the cultivated area is its own, which translates positively in terms of sustainability for the producer.

In order to soy cultivation process, the producers pointed out the main actions they take, reflecting their responsibility for factors related to sustainability in production. There is the use of various inputs and cultivation techniques that favor greater productivity, however, according to technical-agronomic indications, the parameters used are within normal limits. Soil care in soy production is also evident through the option of diversifying crops by most producers, in addition to the option of direct planting, which helps to preserve this natural resource.

For the economic terms, the average reproduction of the 2019 harvest among the samples was 64 bags per hectare and the production cost indicated by most producers as being higher than that of the previous harvest. This information reflects the importance of the production of this grain both in a local, regional and national context. A soybean chain fosters the economy at a pace that involves several types of companies, from industries of agricultural inputs and equipment, commerce and provision of services related to this area.

As the social aspect, it can be inferred that these factors are partly related to environmental concern, that is, by being careful with natural resources, producers demonstrate a certain social responsibility with soy production and how it influences in the context where it is inserted. Still, it was found that most of the producers are linked to some social entity in their surroundings, in addition to directing attention to issues of quality of life for them and the workers who work on their properties.

From the correlation of the profile variables of the producers and the properties with the average of each of the environmental, economic and social dimensions, some significant associations were identified. For example, it was confirmed that the greater the education of producers, the greater the attention to issues related to the care and preservation of the environment.

Although satisfactory evidence was construct in the study, the sample factor and the subjectivity surrounding this type of study are mentioned as a limitation of this research. There was difficulty in reaching a higher number of respondents due to the producers' resistance in declaring the actions they take in soy production and how they think sustainability in this activity, especially due to the use of certain inputs and the exposure of economic and financial issues of their production. Thus, it is suggested that future studies may work with a larger sample size, in addition to seeking to improve theoretical issues related specifically to soy production, which can support the formulation of research instruments that can more accurately measure sustainability in this area on the productive activity.

\section{References}

Conab - Companhia Nacional de Abastecimento. (2019). Acompanhamento da safra brasileira de grãos. Observatório Agrícola, 6(8). Retrieved from https://www.conab.gov.br/info-agro/safras

Cooper, D. R., \& Schindler, P. S. (2016). Métodos de pesquisa em administração. Porto Alegre: Bookman.

Dias, R. (2006). Gestão ambiental: responsabilidade social e sustentabilidade. São Paulo: Atlas.

Donaire, D. (1999). Gestão ambiental na empresa. São Paulo: Atlas.

Elkington, J. (1997). Canibals with forks: the triple bottom line of 21 century business. Oxford: Capstone Publishing. https://doi.org/10.1002/tqem.3310080106 
Elkington, J. (2004). Enter the Triple Bottom Line: does it all add up? London: Earthscan.

Ferreira, C. C., Ferri, C. M., Santos, N. S. M., Hirakuri, M. H., \& Vieira, S. F. A. (2017). A sustentabilidade da cadeia produtiva de soja: avaliação de indicadores de sustentabilidade na microrregião de Cascavel Paraná/Brasil. XVII Congresso Latino-Iberoamericano de Gestión Tecnologica. Ciudad de México. Retrieved from https://ainfo.cnptia.embrapa.br/digital/bitstream/item/172690/1/ALTEC-2017-paper-229.pdf

Froehlich, C. (2014). Sustentabilidade: dimensões e métodos de mensuração de resultados. Desenvolve-Revista de Gestão do Unilasalle, 3(2), 151-168. http://doi.org/10.18316/1316

Gazzoni, D. L. (2013). A sustentabilidade da soja no contexto do agronegócio brasileiro e mundial. Londrina: Embrapa Soja.

Hirakuri, M. H., Castro, C., Franchini, J. C., Debiasi, H., Procópio, S. O., \& Balbinot Júnior, A. A. (2014). Indicadores de sustentabilidade da cadeia produtiva da soja no Brasil Londrina: Embrapa Soja.

Hirakuri, M. H., \& Lazzarotto, J. J. (2014). O agronegócio da soja nos contextos mundial e brasileiro. Londrina: Embrapa Soja.

Ibge. (2017). Censo agro 2017. Retrieved from https://censos.ibge.gov.br/agro/2017/

Instituto Ethos. (2018). Indicadores Ethos para negócios sustentáveis e responsáveis: ciclo 2017/2018. São Paulo: Instituto Ethos de Empresas e Responsabilidade Social.

Kamali, F. P., Meuwissen, M. P. M., Boer, I. J. M., Middelaar, C. E., Moreira, A., \& Lansink, A. G. J. M. O. (2017). Evaluation of the environmental, economic, and social performance of soybean farming systems in southern Brazil. Journal of Cleaner Production, 142, 385-394. https://doi.org/10.1016/j.jclepro.2016.03.135

Kertész, Z., Hegyi, A., Stolz, H., Jahrl, I., Sebök, A., Garibay, S., ... Zanasi, C. (2014). Opinions of stakeholders and consumers on the sustainability of the soy and beef supply chain in Latin America and Europe. International European Forum on System Dynamics and Innovation in Food Networks. Retrieved from https://ideas.repec.org/p/ags/iefi14/199066.html

Lima, M., Silva Júnior, C. A., Rausch, L., Gibbs, H. K., \& Johann, J. A. (2019). Demystifying sustainable soy in Brazil. Land Use Policy, 82, 349-352. https://doi.org/10.1016/j.landusepol.2018.12.016

Limón, J. A. G., \& Fernandez, G. S. (2010). Empirical evaluation of agricultural sustainability using composite indicators. Ecological Economics, 69, 1062-1075. https://doi.org/10.1016/j.ecolecon.2009.11.027

Linch, J., Donnellan, T., Finn, J. A., Dillon, E., \& Ryan, M. (2019). Potential development of Irish agricultural sustainability indicators for current and future policy evaluation needs. Journal of Environmental Management, 230, 434-445. https://doi.org/10.1016/j.jenvman.2018.09.070

Malhotra, N. K. (2012). Pesquisa de marketing: uma orientação aplicada. Porto Alegre: Bookman.

Marconato, D. A. B., Trevisan, M., Pedrozo, E. A., Saggin, K. D., \& Zonin, V. J. (2013). Saindo da trincheira do desenvolvimento sustentável: uma nova perspectiva para an análise e a decisão em sustentabilidade. Revista Administração Mackenzie, 14(1), 15-43. https://doi.org/10.1590/S1678-69712013000100002

Nascimento, E. P. (2012). Trajetória da sustentabilidade: do ambiental ao social, do social ao econômico. Estudos Avançados, 26(74), 51-64. https://doi.org/10.1590/S0103-40142012000100005

Oviedo, E. D. (2015). Argentina and China: an analysis of the actors in the sybean trade and the migratory flow. Journal of Chinese Political Science, 20, 243-266. https://doi.org/10.1007/s11366-015-9360-4

Patias, T. Z. (2017). Inovação social e sustentabilidade em arranjos produtivos locais de agroindústria familiar. Unpublished doctoral dissertation. Universidade Federal de Santa Maria, Santa Maria, Brazil.

Pawlowski, A. (2008). How many dimensions does sustainable development have? Sustainable Development, 16(2), 81-90. https://doi.org/10.1002/sd.339

Pestana, M. H., \& Gageiro, J. N. (2003). Análise de dados para ciências sociais: a complementaridade do SPSS. Lisboa: Edições Silabo.

Petry, J. (2008). Agricultural sustainability: concepts, principles and evidence. Philosophical Transactions of the Royal Society, 363, 447-465. https://doi.org/10.1098/rstb.2007.2163

Prates, C. C., Campos, S., \& Silva, T. N. (2015). A sustentabilidade no campo de gestão e negócios: um retrato 
do tema. Gestão Contemporânea (FAPA), 17, 01-26.

Rampazzo, L. (2002). Metodologia científica: para alunos dos cursos de graduação e pós-graduação. São Paulo: Loyola.

Roos, S. A., Westerfield, R. W., Jordan, B. D., \& Lamb, R. (2015). Fundamentos de administração financeira. Porto Alegre: Bookman.

Ruttan, V. W. (1999). The transition to agricultural sustainability. Proc. Natl. Acad. Sci., 96, 5960-5967. https://doi.org/10.1073/pnas.96.11.5960

Santana, A. C. (2005). Elementos de economia, agronegócio e desenvolvimento local. Belém: GTZ.

Schaller, N. (1993). The concept of agricultural sustainability. Agriculture, Ecosystems and Environment, 46, 89-97. https://doi.org/10.1016/0167-8809(93)90016-I

Spangerber, J., \& Bonniot, O. (1998). Sustainability indicators: a compasso $n$ the road towards sustainability (p. 81). Wuppertal Institute. Retrieved https://epub.wupperinst.org/frontdoor/deliver/index/docId/721/file/WP81.pdf

Sydorovych, O., \& Wossink, A. (2008). The meaning of agricultural sustainability: evidence from a conjoint choice survey. Agricultural Systems, 98, 10-20. https://doi.org/10.1016/j.agsy.2008.03.001

Tilman, D., Cassman, K. G., Matson, P. A., Naylor, R., \& Polasky, S. (2002). Agricultural sustainability and intensive production practices. Nature, 418, 671-677. https://doi.org/10.1038/nature01014

Werbach, A. (2010). Estratégia para sustentabilidade: uma nova forma de planejar sua estratégia empresarial. Rio de Janeiro: Elsevier.

Xavier, A., Freitas, M. B. C., Fragoso, R., \& Rosário, M. S. (2018). A regional composite indicator for analysing agricultural sustainability in Portugal: a goal programming approach. Ecological Indicators, 89, 84-100. https://doi.org/10.1016/j.ecolind.2018.01.048

Zortea, R. B., Maciel, V. G., \& Passuello, A. (2018). Sustainability assessment of soybean production in Southern Brazil: a life cycle approach. Sustainable Production and Consumption, 13, 102-112. https://doi.org/10.1016/j.spc.2017.11.002

\section{Copyrights}

Copyright for this article is retained by the author, with first publication rights granted to the journal.

This is an open-access article distributed under the terms and conditions of the Creative Commons Attribution license (http://creativecommons.org/licenses/by/4.0/). 